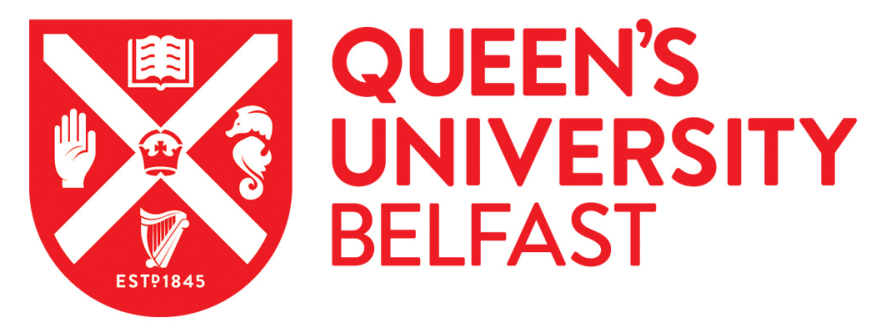

\title{
HLA gene and haplotype frequencies in a Nagaybaks population from the Chelyabinsk Region (Russian South Urals)
}

Suslova, T. A., Burmistrova, A. L., Vavilov, M. N., Chernova, M. S., Khromova, E. B., Belyaeva, S. V., Zaripova, O. N., Stashkevich, D. S., Galkin, A. S., \& Darke, C. (2017). HLA gene and haplotype frequencies in a Nagaybaks population from the Chelyabinsk Region (Russian South Urals). Human Immunology. https://doi.org/10.1016/j.humimm.2017.08.005

Published in:

Human Immunology

Document Version:

Peer reviewed version

Queen's University Belfast - Research Portal:

Link to publication record in Queen's University Belfast Research Portal

\section{Publisher rights}

Copyright 2017 Elsevier

This manuscript is distributed under a Creative Commons Attribution-NonCommercial-NoDerivs License

(https://creativecommons.org/licenses/by-nc-nd/4.0/), which permits distribution and reproduction for non-commercial purposes, provided the author and source are cited.

\section{General rights}

Copyright for the publications made accessible via the Queen's University Belfast Research Portal is retained by the author(s) and / or other copyright owners and it is a condition of accessing these publications that users recognise and abide by the legal requirements associated with these rights.

Take down policy

The Research Portal is Queen's institutional repository that provides access to Queen's research output. Every effort has been made to ensure that content in the Research Portal does not infringe any person's rights, or applicable UK laws. If you discover content in the Research Portal that you believe breaches copyright or violates any law, please contact openaccess@qub.ac.uk. 
HLA gene and haplotype frequencies in a Nagaybaks population from the Chelyabinsk Region (Russian South Urals)

T.A. Suslova, ${ }^{\dagger} \uparrow$ A.L. Burmistrova, * M.N. Vavilov, $\uparrow$ M.S Chernova, * E.B. Khromova,

* S.V. Belyaeva, * $\dagger$ O.N. Zaripova, * D.S.Stashkevich,* † A.S.Galkin \$, \& C.Darke $\|$

* Chelyabinsk State University, Chelyabinsk, Russia.

$\dagger$ Chelyabinsk Regional Blood Transfusion Station, Chelyabinsk, Russia.

† Brain and Mind Research Institute Cornell Medical College, New York, USA \& School of Biological Sciences, Queens University Belfast, Belfast, UK

|| Welsh Transplantation and Immunogenetics Laboratory, Welsh Blood Service, Wales, UK

Correspondence: Dr. T. A. Suslova, Biology Faculity, Chelyabinsk State University, Br. Kashirinih str, 129, Chelyabinsk, 454021, Russia.

Tel: +7 (351) 2327894

Fax: +7 (351) 7997125

E-mail: tatiana.suslova.hla@gmail.com

Key words: population studies, HLA, Histocompatibility, allele frequencies, population genetics, Nagaybaks, Chelyabinsk Region 


\begin{abstract}
A total of 112 Nagaybaks, a Turkic ethnoconfessional group living mainly in the Nagaybak district of the Chelyabinsk Region of Russian South Urals, were genotyped for HLA-A, -B, DRB1, -DQA1 and -DQB1 loci using PCR-SSP (low-resolution) and HLA-A29 (highresolution). All loci were in Hardy-Weinberg equilibrium (all $p$ values $>0.1$ thus showing no locus-level deviations. The genotype data are available in the Allele Frequencies Net Database under the population name "Russia, South Ural, Chelyabinsk Region, Nagaybaks" and the identifier (AFND0003397).
\end{abstract}


Nagaybaks (Nağaybäks, Nogaybaks, Nogoybaqs) are a Turkic ethnoconfessional group that is close to the Kryashen Tatars. They live mainly in the Nagaybak district of the Chelyabinsk Region. According to the latest census (National Population Census, 2010) some 7,679 Nagaybaks, comprising $94.2 \%$ of all Nagaybaks in Russia, live in the Chelyabinsk Region.

There are several theories regarding Nagaybak ethnogenesis. The first states that Nagaybaks originated from the Volga region and supposedly are descendants of Nogay and Kipchak peoples, the general population of the Nogai Horde [1]. The Nogai Horde was formed in the 15th/16th Centuries after the collapse of the Golden Horde on the left bank of the lower Volga, the territory of today's Bashkortostan, Chelyabinsk and Orenburg Regions and western and central Kazakhstan. Another version of Nagaybaks' ethnogenesis suggests that ancestors of Nagaybaks came from Kazan Khanate, another state formed after the collapse of the Golden Horde. The Arsk region was a part of Kazan Khanate. A further theory states that the Nagaybaks were Tatarized Finno-Ugric peoples that kept the Kazan Khanate's borders [1].

Early historical records indicate that since ancient times and up until 1736 Nagaybaks lived separately from Bashkirs and Tatars away from Russian cities and villages in Ufa Country (today's Bashkiria). They spoke a dialect of the Tatar language, professed orthodoxy and paid tribute to the Russian Tsar. In 1736 the Russian tsarist government built a town for them and named it the "Nagaybak's Fortress". The inhabitants were called "Nagaybaks" and they became Cossacks under the decree of the empress.

In 1773 the Nagaybak population of the Fortress and surrounding 14 villages was about 2,000. But among them there were some 200 other nationalities, including Bashkirs and others, notably Persians, Arabs, Arabians, Armenians, Afghans and Turks. CossackNagaybaks, as a military caste, took part in all internal Russian conflicts and foreign campaigns of Russia since the 18th century. In 1864, according to imperial decree, the Nagaybaks were ordered to move to the territory of the modern Nagaybak's districts of the Chelyabinsk Region called Parizh, Cassel and Fershampenuaz. They moved due to changes in the borders of Russia and the establishment of fortresses and Cossack settlements on the "New Orenburg line". Thus, the majority of Nagaybaks have lived in the Chelaybinsk Region from around 1864 to the present day.

It is clear that the Nagaybaks were in geographic and cultural isolation from their main body of close relatives, the Volga-Urals Tatars. By the beginning of the 20th century Nagaybaks had acquired traits expected of an ethnologically-independent unit and spoke a sub-dialect of the Tatar language [1]. 
All subjects were normal, healthy unrelated blood donors, of between 18 and 55 years of age, living in the Chelyabinsk Region (South Urals, Russia). Their ethnic origin was determined by a comprehensive questionnaire. Only subjects with a Nagaybaks origin spanning at least three generations were included in the study. All 112 Nagaybaks (54 men and 58 women) were Russian language speakers and some 95\% spoke the Nagaybaks language (a dialect of the Tatar language). One hundred and nine lived in the Nagaybak's districts of the Chelyabinsk Region (38 from Kassel'skij, 31 from Fershampenuaz, 19 from Parizh, 16 from Ostrolenka and 5 from Nagajbakskij) (Supplementary Figure 1). The remaining 3 came from other cities of the Region. DNA was obtained from EDTAanticoagulated peripheral blood using AxyPrep spin columns (AxyPrep_Blood Genomic DNA Miniprep Kit; Axygen Biosciences, Union City, CA, USA) according the manufacturer's protocol.

HLA-A, -B, -DRB1 and -DQB1 typing was performed by PCR using sequence-specific primers (SSP). The primers and primer mixtures used were essentially those of Downing et al. [2]. HLA-DQA1 typing to the 2nd field and HLA-A*29 typing, to the 2nd field, was undertaken using commercial kits (One Lambda, Canoga Park, CA, USA).

Population genetics analysis was performed as described by Schipper et al. [3]. The validity of Hardy-Weinberg equilibrium and homozygosity was tested for each locus. Carriage frequencies (cf) and gene frequencies (gf) were determined by direct counting and maximum likelihood, respectively. Two- and three-locus haplotype frequency (HF) estimates were calculated by maximum likelihood. The linkage disequilibrium (LD) parameter $(\Delta)$, the relative magnitude of the delta value $(\Delta \mathrm{rel})$ and the significance of delta values for two- and three-locus haplotypes were determined as previous described [4].

HLA-A, -B and -DRB1 frequency data were used for the construction of a dendrogram using the maximum likelihood method (PHYLIP version 3.68) [5]. Thus, the Nagaybak population was compared with populations of Russians, Tatars and Bashkirs of the Chelyabinsk Region [6] and with 18 other populations [6, 7, 8, 9, 10]. The findings of the Hardy-Weinberg and homozygosity analyses for HLA-A, -B, -DRB1, -DQA1 and -DQB1 all showed an acceptable goodness-of-fit for both phenotype distribution and the number of likely homozygotes identified (all p values >0.1). Allele family frequencies are presented in Supplementary Table 1, 2-loci HF and LD data in Supplementary Table 2, 3-loci HF and LD data in Supplementary Table 3, and 5-loci HF data in Supplementary Table 4. Supplementary Table 5 shows the findings of HLA-A*29 typing to the 2 nd field. Prior to taking blood samples full informed consent for the collection and use of specimens was given by all 
donors. All obtained data are publically available at Allele Frequencies Net Database AFND0003397.

A dendrogram, comparing the Nagaybak population with other populations of the Chelyabinsk Region and populations worldwide, is presented in Supplementary Figure 2.

This study was supported by the Russian Foundation for Basic Research within research project number 15-04-05176 and by MRC grant MR/L007339/1. 


\section{References}

[1] I.R. Atnagulov, Material culture and subsistence Verkhneuralsk, Cossack, Nagaybaks, second half of XIX - early XX centuries. PhD thesis, Institute of Archaeology and Ethnography of the Siberian Branch of the Russian Academy of Sciences, Novosibirsk, 2002.

[2] J. Downing, M.G. Guttridge, J. Thompson, C. Darke, Five-locus HLA typing of hematopoietic stem cell donor volunteers using PCR sequence specific primers, Genetic Testing. 8 (2004) $301-312$.

[3] R.F. Schipper, J. D'Amaro, J.T. Bakker, J. Bakker, J.J. van Rood, M. Oudshoorn, HLA gene haplotype frequencies in bone marrow donors worldwide registries. Human Immunology. 52 (1997) $54-71$.

[4] C. Darke, M.G. Guttridge, J. Thompson, S.McNamara, J. Street, M. Thomas, HLA class I (A, B) and II (DR, DQ) gene and haplotype frequencies in blood donors from Wales. Experimental and Clinical Immunogenetics. 15 (1998) 69 - 83.

[5]. Felsenstein, PHYLIP (Phylogeny Inference Package). Version 3.68. Distributed by the author. Department of Genome Sciences, University of Washington, Seattle, WA. Available from: http://evolution.gs.washington.edu/phylip 2008 (accessed 08.06.2017).

[6] T.A. Suslova, A.L. Burmistrova, M.S. Chernova, E.B. Khromova, E.I. Lupar, S.V.Timofeeva, et al. HLA gene and haplotype frequencies in Russians, Bashkirs and Tatars, living in the Chelyabinsk Region (Russian South Urals). International Journal of Immunogenetics. 39 (2012) 394 - 408.

[7] F.F. Gonzalez-Galarza, L.Y. Takeshita, E.J. Santos, F. Kempson, M.H. Maia, A.L. da Silva et al. Allelefrequency net 2015 update: new features for HLA epitopes, KIR and disease and HLA adversedrug reaction associations. Nucleic Acids Research. 43 (2015) D784-8. doi:10.1093/nar/gku1166.

[8] M.H. Park, H.S. Kim, S.J. Kang, HLA-A,-B,-DRB1 allele and haplotype frequencies in 510 Koreans. Tissue Antigens. 53 (1999) 386 - 390. 
[9] A. Wennerström, E. Vlachopoulou, L.E. Lahtela, R. Paakkanen, K.T. Eronen, M. Seppänen, M.L. Lokki Diversity of extended HLA-DRB1 haplotypes in the Finnish population, PLoS One. 8 (2013) e79690.

[10] A. Johansson, M. Ingman, S.J. Mack, H. Erlich, U. Gyllensten, Genetic origin of the Swedish Sami inferred from HLA class I and class II allele frequencies, Eur. J. Hum. Genet. 16 (2008) 1341 - 1349. 